\title{
寒冷地に建設される浮体構造物に対する水の影響について
}

Ice Influences on the Floating Structures in Cold Regions

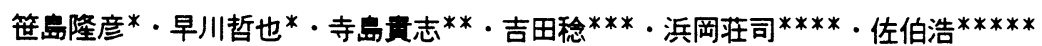

Takahiko Sasajima,Tetsuya Hayakawa,Takashi Terashima,Minoru Yoshida,Shouji Hamaoka,Hiroshi Saeki

\begin{abstract}
This paper presents the ice influences on the floating structures in cold regions. Recently the marine recreation such as yachts and motorboats becomes popular in Japan. In Hokkaido, four public marinas are constructed in the coast of the Pacific Ocean and the Sea of Japan. This leads the marine activities more popular. But no marinas have been constructed in the coast of the Sea of Okhotsk where sea ice cause many problems to the marina structures. On the other hand, a lot of marinas are constructed in the coast of Northern Europe under the same climatic conditions as the Sea of Okhotsk, and marinas are used actively except the period when harbors are covered by sea ice. In this paper, the authors propose the design methods for marina facilities considering the ice influences on the floating structures.

Keywords: floating structures, cold regions, ice influences
\end{abstract}

1.はじめに

近年、我が国においてはヨットやモーターボートといったプレジャーボートによる海洋性レクリエーションが 活発になってきている。北海道においても、これらの海洋性レクリエーションに対する需要は高く、冬期間港内 結水や流氷の影響を受けるオホーツク海沿岸においてもその需要は高い。

このような結水海域に建設されるマリーナやプレジャーボート用の施設の設計に際しては、氷の影響を十分に 考虑する必要がある。

本研究では、特にマリーナ等で用いられる浮体構造物に対してどのような設計方法をとるべきかを考察するこ とを目的とし、紋別港において浮体構造物に対する氷の影響に関する現地実験を実施したものである。

\section{2. 現地実験の方法}

2-1.実験サイト

現地実験は、概ね 1 月下旬より 3 月中旬まで結水する北海道オホーツク海沿岸に面する重要港湾の紋別港 第四船溜で実施した。

2-2. 実験項目

実験項目は、以下の2点である。

(1)結水状況の観測

第四船溜及び浮体構造物周辺の結氷状況を観測する。

(2)浮体の観測

浮体構造物の四隅をレベル測量することにより、浮体の鉛直変位量を測定する。また、浮体構造物の 2 点 を測角することにより、浮体の水平変位量を測定する。

2-3.実験に用いた浮体と係留方法

調査に用いる浮体は、以下に示す 4 種類である。

・浮体 $\mathrm{A}$ ：白色の直方体を岸壁より $2 \mathrm{~m}$ 離して設置

・浮体 $\mathrm{B}$ : 白色の傾斜角を有した浮体を岸壁より $10 \mathrm{~m}$ 離して設置

・浮体 C : 白色の直方体を岸壁より $10 \mathrm{~m}$ 離して設置

・浮体 D : 黒色の直方体の浮体を岸壁より $10 \mathrm{~m}$ 離して設置

\begin{tabular}{rrlll}
\hline$*$ & 正会員 & 北海道開発局 & & \\
$* *$ & 正会員 & パシフィックンサルタンツ（株）（060 札幌市北区北7条西 1丁目） \\
$* * *$ & 正会員 & (株) 西村組 & & \\
$* * * *$ & 正会員 & (株) オホーツク流水科学研究所 & \\
$* * * *$ & 正会員 北海道大学工学部
\end{tabular}


これらの浮体に対して、港内結水時における水平及び鉛直方向の变位, 結氷状況等を調べることにより、 結水海域において浮体を設置する場合の岸壁からの適切な距離、浮体の契水部の適切な角度, 浮体に適した 色等を明らかにするものである。

図 1 に各浮体の平面配置及び係留力法をホす。
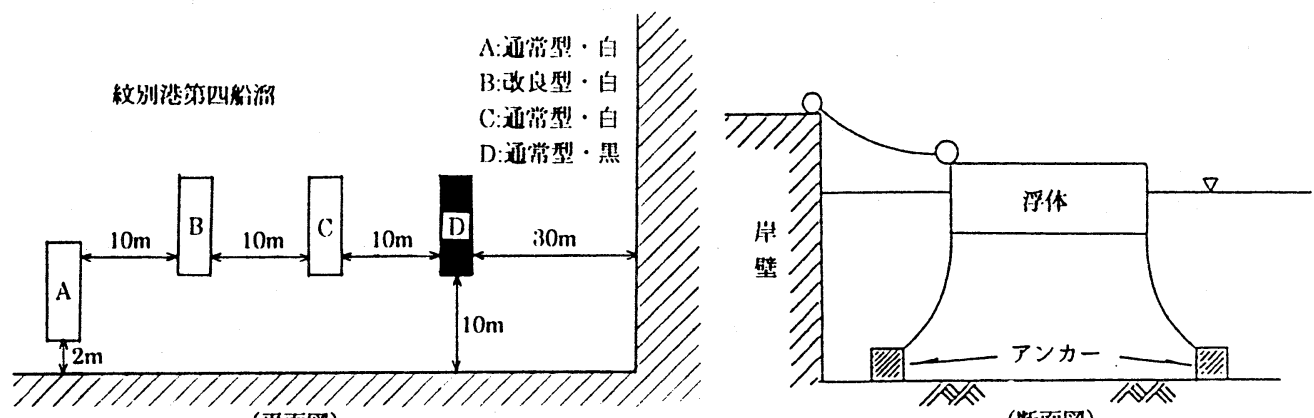

(平而図)

図1各浮体の平面配置及び係留方法

\section{3. 実験結果}

3-1.結水状況の観測結果

表 1 に結氷状況の総括表を示す。

これによると、第四船溜については、H8.2.5 にはほぼ全体的な結氷に至ったが、その後の暖気により H8.2.13〜H8.2.19 にかけては非結水や蓮の葉氷の範囲が広くなった。しかし、再び寒気にはいり $\mathrm{H} 8.2 .22$ 以降は完全結氷となった。

一方、浮体周辺については、H8.2.8には全ての浮体に氷盤が凍着していたが、その後の暖気により、H8.2.13 には浮体 $\mathrm{B}$ 及び $\mathrm{C}$ は部分的に凍着、浮体 D は凍着しなかった。しかし、浮体 $\mathrm{A}$ だけは完全に凍着していた。 $\mathrm{H} 8.2 .16$ 以降は、浮体 $\mathrm{A}, \mathrm{B}$ 及び $\mathrm{C}$ は完全に凍着、浮体 D は部分的に凍着していた。H8.3.7 以降は、暖気に より水がゆるみ、蓮の葉水が浮体と接している状況だった。

なお、部分的に凍着している場合の非凍着面は日光の当たる東側及び南側であった。

表 1 結水状況の総括表

\begin{tabular}{|c|c|c|c|}
\hline 年月日 & 第四船溜 & 浮体周辺 & 備 \\
\hline H8.2.5 & $\begin{array}{l}\text { ・波除堤の開口部のみ非結氷，他は } \\
\text { 全体的に結氷 }\end{array}$ & $\begin{array}{l}\text { - 浮体 A は完全に凍着, B,C 及び } \\
\text { D は東側と南側が非凍着 }\end{array}$ & \\
\hline H8.2. 8 & - 同上 & ・全ての浮体に氷盤が凍着 & \\
\hline H8.2.13 & $\begin{array}{l}\cdot \text { · H8.2.8 に比べて非結氷の範囲が広 } \\
\text { い }\end{array}$ & $\begin{array}{l}\text { - 浮体 A は完全に凍着, B 及び C } \\
\text { は部分的に凍着, D は凍着なし } \\
\end{array}$ & \\
\hline H8.2.16 & $\begin{array}{l}\text { ・開口部から物揚場にかけて大きな } \\
\text { 蓮の葉氷, これより北側で部分的 } \\
\text { に非結水，他は結氷 }\end{array}$ & $\begin{array}{l}\text { - 浮体 A,B 及び C は完全に凍着. } \\
\text { D は部分的に凍着 }\end{array}$ & \\
\hline H8.2.19 & $\begin{array}{l}\text { ・H8.2.16 に比べて蓮の葉水の範囲 } \\
\text { が広い。ただし、非結皮のエリア } \\
\text { はない }\end{array}$ & - 同 上 & \\
\hline H8.2.22 & - 完全結水 & - 同上 & \\
\hline H8.2.24 & - 同 上 & $\begin{array}{l}\text { - 浮体 A,B 及び C は完全に凍着. } \\
\text { D は部分的に凍着 }\end{array}$ & \\
\hline H8.2.26 & - 同上 & - 同上 & \\
\hline H8.2.29 & - 同上 & - 同上 & \\
\hline H8.3.7 & ·全体的に氷がゆるみ蓮の葉办 & $\begin{array}{l}\text { ・办盤と接してはいるが凍着はし } \\
\text { ていない }\end{array}$ & \\
\hline H8.3.11 & - 同上 & - 同 上 & \\
\hline
\end{tabular}


3-2. 浮体の観測結果

(1) 全期間の鉛直変位

図2 に全期間の $\mathrm{X}$ 方向鉛直変位の経時変化を示す。X 方向とは浮体の短辺方向（東西方向）. $\mathrm{Y}$ 方向は 浮体の長辺方向（南北方向）と定義する。

$\mathrm{X}$ 方向の鉛直変位量は、 $\mathrm{X}$ 軸と直角方向の 2 点の平均値同志の差である变位量が正の場合は浮体の西側 が高く、東側が低くなっている状態を意味する。眓中の平均值は、33 回の観測值の平均値で、 $\mathrm{x}$ 方向の変 位量は浮体 B が $3.7 \mathrm{~cm}$ で最も大きく、浮体 D が $2.0 \mathrm{~cm}$ で最も小さいが大きな差はない。

一方、図3に Y 方向鉛直変位の経時変化を示す。変位量が正の場合は、浮体の北側が高く、南側が低 くなっている状態を意味する。これによると、Y 方向の变位量は、浮体 $\mathrm{A}$ が $10.2 \mathrm{~cm}$ で最も大きく、浮体 Cが $0.9 \mathrm{~cm}$ で最も小さい。

(2) 1 日周期の鉛直変位

図4に 1 日周期の X 万向鉛直変位量の経時変化を示す。これによると、X 方向の変位量は、浮体 $\mathrm{B}$ が $3.5 \mathrm{~cm}$ で最も大きく、浮体 D が $1.3 \mathrm{~cm}$ で最も小さいが大きな差はない。

一方、図 5 に Y 方向鉛直変位量の経時変化を示す。これによると、Y 方向の变位量は、浮体 $\mathrm{A}$ が $7.0 \mathrm{~cm}$ で最も大きく、浮体 C 及び D が $1.2 \mathrm{~cm}$ で最も小さい。

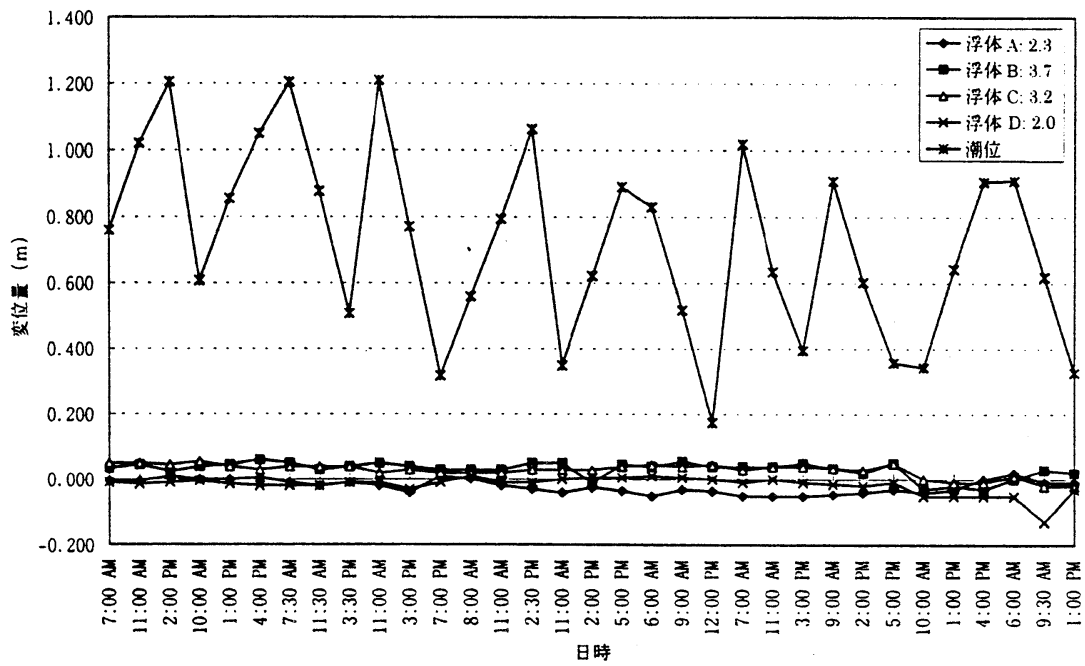

図2 $\mathrm{x}$ 万向鉛直変位の経時変化（全期間）

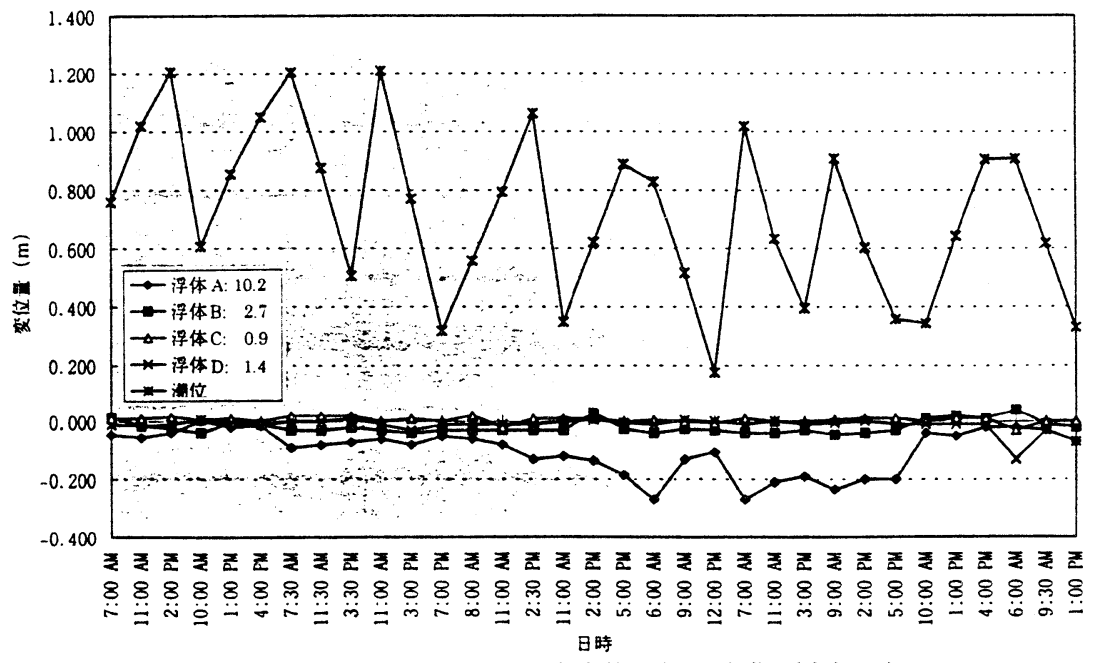

困3 Y 方向鉛直変位の経時変化（全期間） 


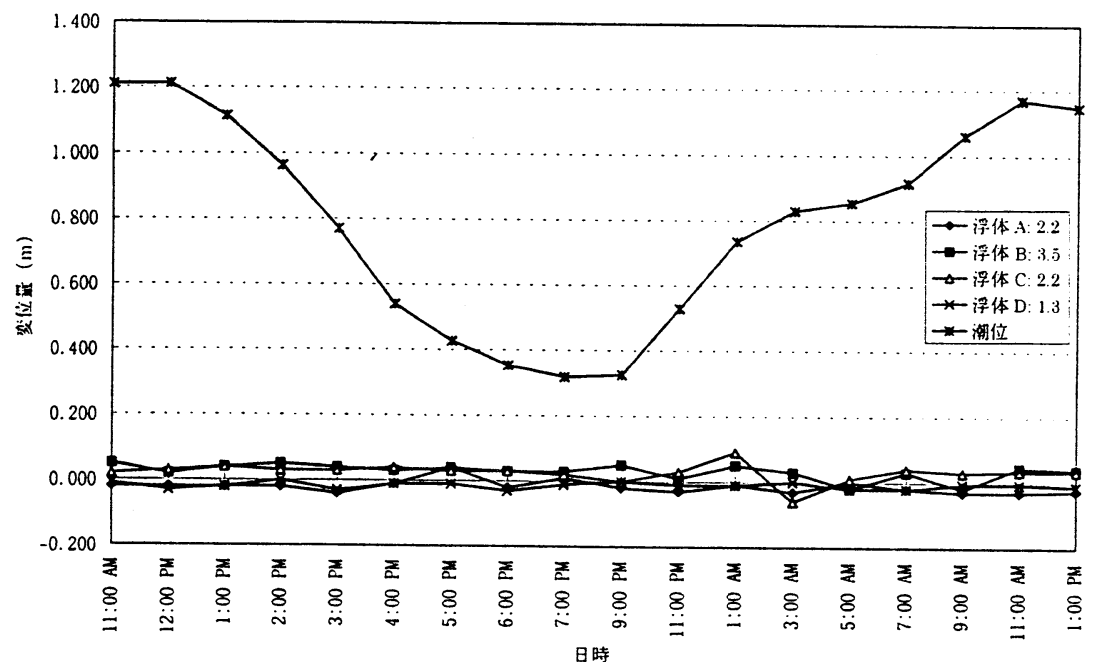

図4 $\mathrm{X}$ 方向鉛直変位の経時変化（1 日周期）

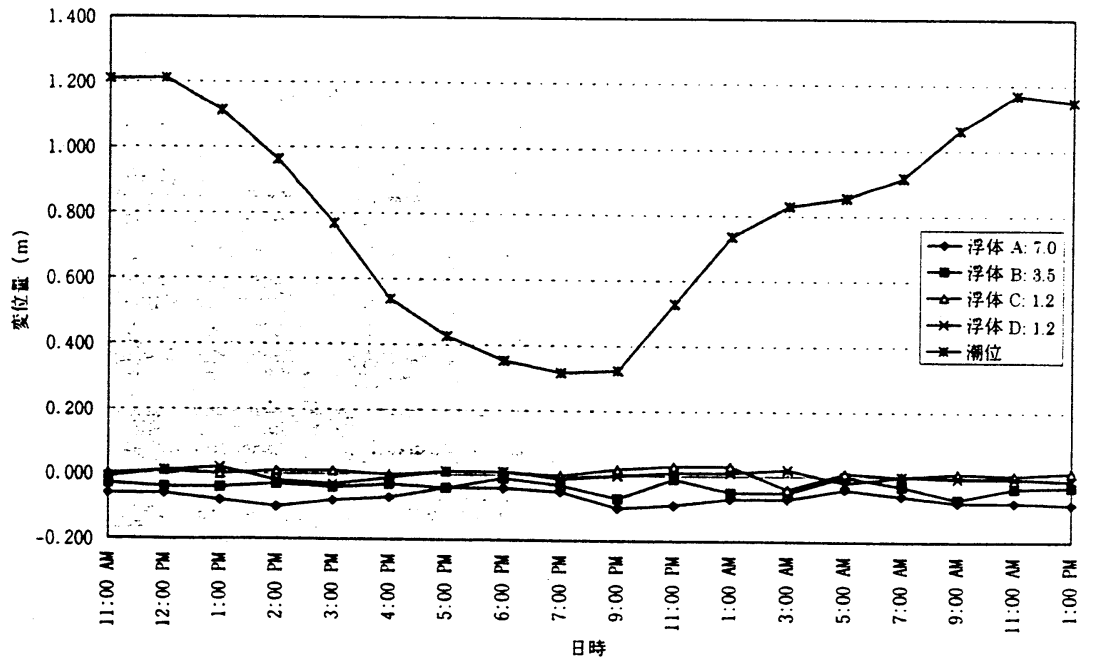

図5 Y 方向鉛直変位の経時変化 (1 日周期)

(3) 全期間の水平変位

図6に全期間の浮体重心の $\mathrm{x}$ 方向水平変位の経時変化を示す。

また、図7に浮体重心のY方向水平変位の経時変化を示す。

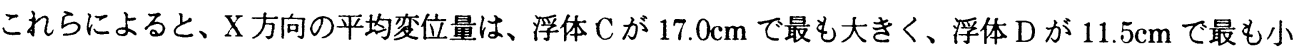
さい。また、 $\mathrm{Y}$ 方向の平均変位量は浮体 $\mathrm{A}$ が $8.7 \mathrm{~cm}$ で最も大きく、浮体 $\mathrm{C}$ が $6.2 \mathrm{~cm}$ で最も小さい。

(4) 1 日周期の水平变位

図8に 1 日周期の浮体重心の $\mathrm{X}$ 方向水平変位の経時変化を示す。また、図 9 に浮体重心の $\mathrm{Y}$ 方向水平 変位の経時変化を示す。

これらによると、 $\mathrm{X}$ 方向の平均変位量は、浮体 $\mathrm{A}$ が $14.6 \mathrm{~cm}$ で最も大きく、浮体 $\mathrm{D}$ が $4.6 \mathrm{~cm}$ で最も小 さい。また、Y 方向の平均変位量は浮体 $\mathrm{A}$ が $3.0 \mathrm{~cm}$ で最も大きく、浮体 $\mathrm{B}$ 及び $\mathrm{C}$ が $2.2 \mathrm{~cm}$ で最も小さい が大きな差はない。 


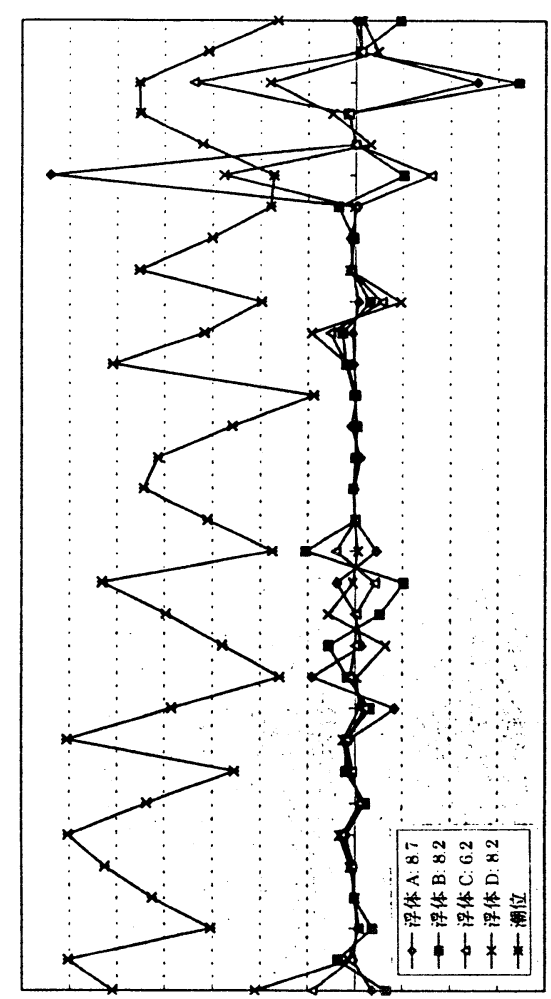

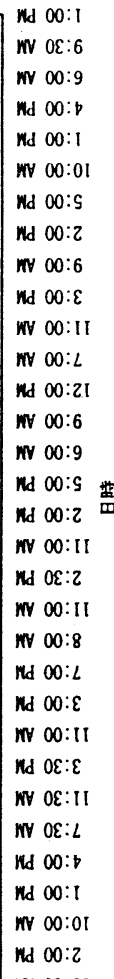

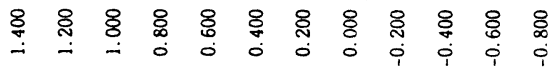

(w) 777

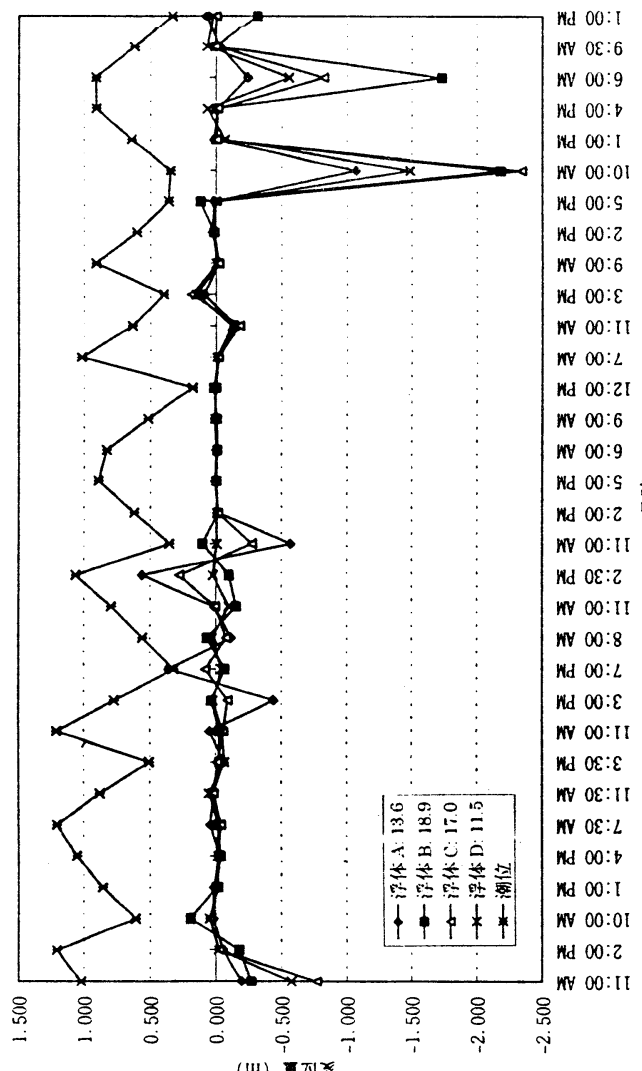

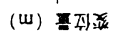
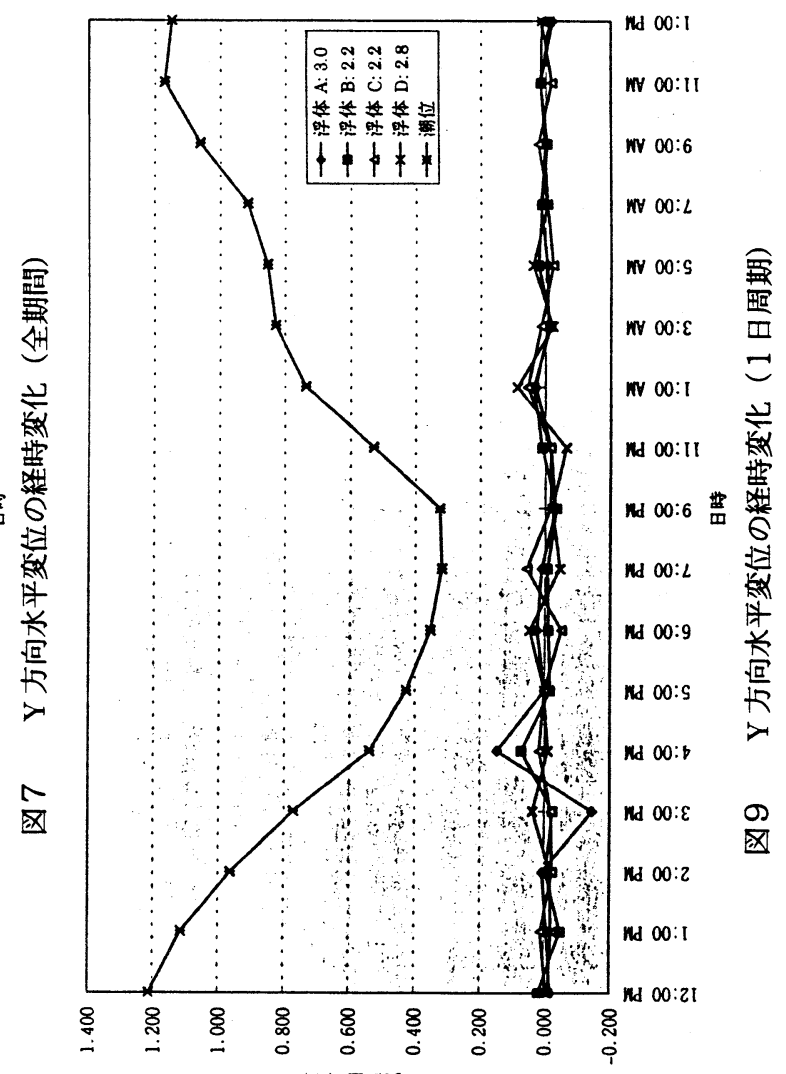

(ui) 풍재

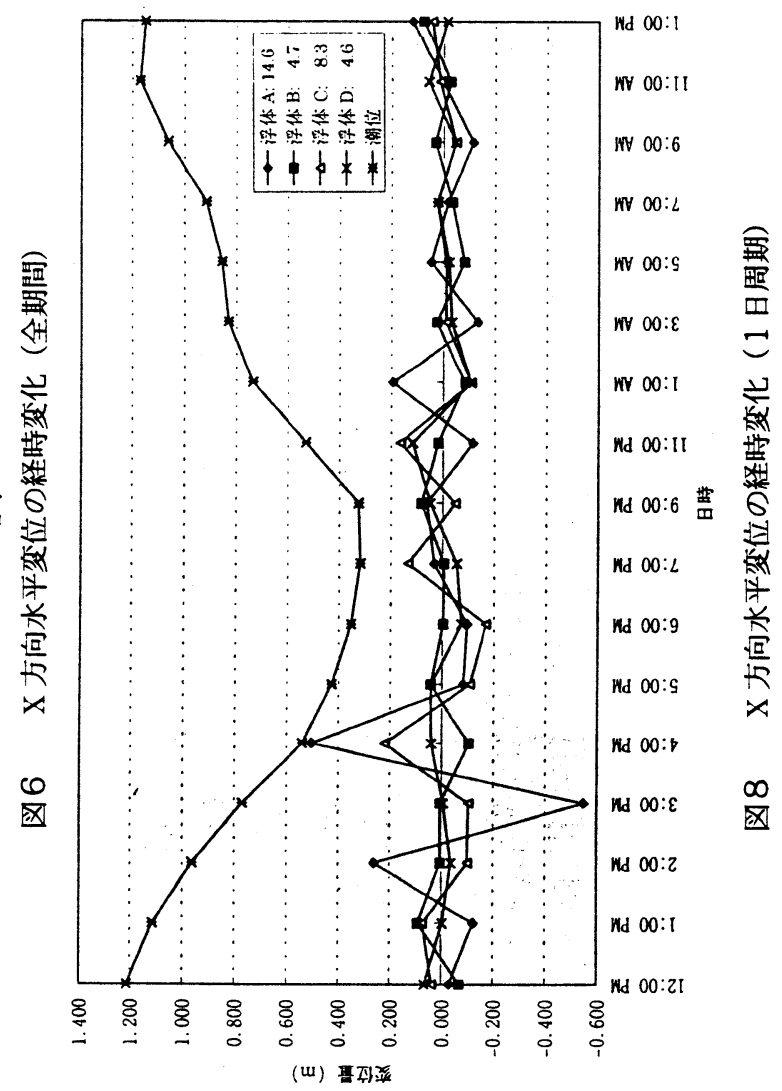


3-3.水の物性

図10に、実験サイトの氷盤の曲け強度と水温との関係を示す。これによると、水盤の曲け強度は 4〜 $7 \mathrm{kgf} / \mathrm{cm}^{2}$ である。

図 11 に、実験サイトの氷盤の圧縮強度と水温との関係を示す。これによると、氷盤の圧縮強度は 5〜 $20 \mathrm{kgf} / \mathrm{cm}^{2}$ で、氷温が低くなると压縮強度は低下する傾向がある。

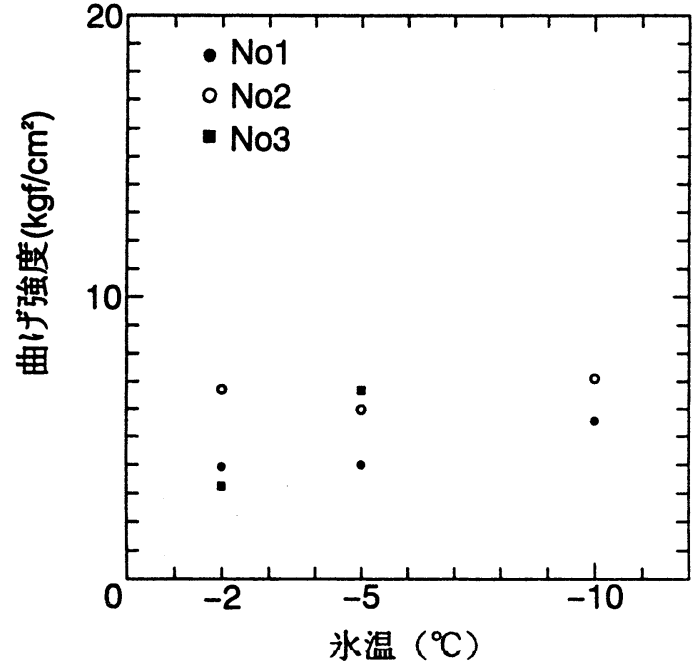

図 10 曲げ強度と氷盤の関係

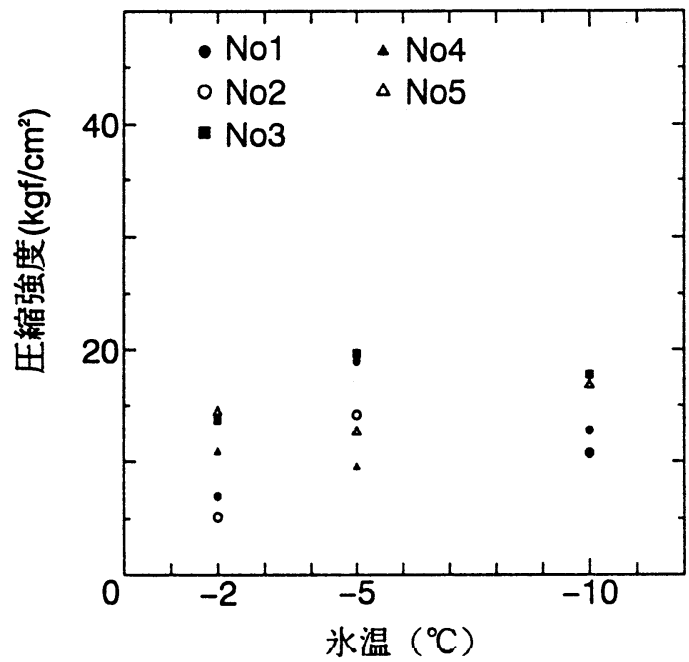

図 11 圧縮強度と氷温の関係

4. まとめ

以上に述べた現地実験の結果を要約すると次のとおりである。

（1）平成 8 年 1 月中旬より 3 月中旬にかけて、紋別港第四船溜に 4 種類の浮体を浮置して観測した結果、第四 船溜の水面は、1月下旬から2月上旬にかけて結氷と氷の流失（融水）を繰り返し、2月 8 日に完全結水 に至った。そして、3月8日には水がゆるみはじめ、その後3月中旬には完全に水は流失（融水）した。

(2) 氷と浮体との凍着の有無を観測した結果、黒色の浮体（浮体 D）には、氷が凍着する頻度が少ない。特に、 日光の当たる東側及び南側の面は、少なくとも昼間は凍着しない場合が多い。

（3）浮体周辺における水の破壊状況を観測した結果、岸壁に最も近い浮体（浮体 A）は水盤の曲け破壊の影響 を強く受ける。また、岸壁から $3 \sim 5 \mathrm{~m}$ 付近で氷盤が曲け破壊を生じており、干潮時から满潮時にかけてフ ラッディング状態となる。

(4) 各浮体の鉛直変位量を計測した結果、 $\mathrm{x}$ 方向の変位量は浮体 D が最も小さく、浮体 $\mathrm{B}$ が最も小さいが大 きな差はない。また、Y 方向の変位量は浮体 C,D が最も小さく、浮体 Aが最も大きい。

(5) 各浮体の水平変位量を計測した結果、 $\mathrm{X}$ 方向の変位量は浮体 D が最も小さく、浮体 A,C が最も大きい。 また、Y 方向の変位量は浮体 $\mathrm{B}, \mathrm{C}$ が最も小さく、浮体 A が最も大きい。

(6) 実験サイトにおける氷盤の曲け強度は 4〜 $7 \mathrm{kgf} / \mathrm{cm}^{2}$, 圧縮強度は $5 \sim 20 \mathrm{kgf} / \mathrm{cm}^{2}$ であった。

(7) 寒冷地における浮体構造物の設計に際しては、以下の点を考慮する必要がある。

(1)水盤の曲け破壊が生じるエリア（岸壁等の境界より 3〜 5m）に浮体を設置しないこと。 (2)浮体の色は白色よりも黒色の方が氷盤が凍着しにくく、また、雪も融けやすい。 (3)今回の実験では、浮体の係留方式はアンカー式としたが、アンカー式の場合には水面が完全に結氷する 時よりも通常時の波浪による影響が大きい。

・笹島·水野·寺島·河合·佐伯：「寒冷地に建設されるマリーナの設計方法について」，海洋開発論文集， Vol.11,1995 年 